\title{
Gambaran profil lipid pada remaja obes di Kota Bitung
}

\author{
${ }^{1}$ Billy Senduk \\ ${ }^{2}$ Widdhi Bodhi \\ ${ }^{2}$ Billy J. Kepel \\ ${ }^{1}$ Kandidat Skripsi Fakultas Kedokteran Universitas Sam Ratulangi Manado \\ ${ }^{2}$ Bagian Kimia Fakultas Kedokteran Universitas Sam Ratulangi Manado \\ email: billysenduk12158@yahoo.com
}

\begin{abstract}
Obesity is a condition of increased body weight because of sexcessive fat accumulation in the body. The prevalence of obesity is increasing becoming one of the things that concern in Indonesia, especially in urban areas. Obesity is also associated with blood lipid levels that can cause dyslipidemia. Lipid profile can be observed by levels of total cholesterol, LDL, HDL, and triglycerides. Dyslipidemia has related with the occurrence of atherosclerosis and lead to acute myocardial infarction. This research used a descriptive observational study with cross sectional design. The samples were taken from adolescents obesity as measured by waist circumference. The amount of sample that is willing to sign an informed consent 50 samples. Based on the measurement of waist circumference of 966 students obtained 220 obese students (22.8\%) and were taken 50 obese students who are willing to become a sample. From the results of blood samples examination of the 50 obese students was obtained 13 students (26\%) had total cholesterol levels above normal, 31 students (62\%) had HDL levels below normal, 41 students (82\%) had LDL levels above normal, and 6 students (12\%) have triglyceride levels above the normal value.
\end{abstract}

Keywords: obesity, adolescents, lipid profile

\begin{abstract}
Abstrak: Obesitas adalah kondisi meningkatnya berat badan akibat akumulasi lemak berlebihan dalam tubuh. Prevalensi obesitas yang terus meningkat menjadi salah satu hal yang dikhawatirkan di Indonesia, terutama di perkotaan. Obesitas juga berkaitan dengan kadar lipid darah yang dapat menyebabkan dislipidemia. Profil lipid adalah keadaan lemak yang dilihat dari kadar kolesterol total, LDL, HDL, dan Trigliserida. Dislipidemia memiliki hubungan erat dengan terjadinya aterosklerosis dan berujung pada infark miokard akut. Penelitian ini dilakukan dengan menggunakan metode observasional deskriptif dengan desain cross sectional study. Sampel penelitian diambil dari remaja obesitas yang diukur berdasarkan lingkar pinggang. Jumlah sampel penelitian yang bersedia menandatangani informed consent 50 sampel. Berdasarkan hasil pengukuran lingkar pinggang 966 siswa didapatkan 220 siswa $(22,8 \%)$ mengalami dan diambil 50 siswa obesitas yang bersedia untuk dijadikan sampel penelitian. Dari hasil pemeriksaan sampel darah terhadap 50 siswa obesitas tersebut didapatkan 13 siswa (26\%) memiliki kadar kolesterol total diatas normal, 31 siswa (62\%) memiliki kadar HDL dibawah normal, 41 siswa (82\%) memiliki kadar LDL diatas normal, dan 6 siswa (12\%) memiliki kadar trigliserida diatas nilai normal.
\end{abstract}

Kata kunci: obesitas, remaja, profil lipid

Obesitas merupakan salah satu tantangan kesehatan masyarakat paling serius di abad ke-21. Masalah obesitas terus meningkat dan mempengaruhi banyak negara-negara di dunia baik negara maju dan negara berkembang, terutama di perkotaan. ${ }^{[1]}$ Obesitas didefinisikan sebagai akumulasi lemak abnormal atau berlebihan yang 
beresiko bagi kesehatan. Derajat obesitas ditentukan dengan pengukuran indeks massa tubuh. ${ }^{[2]}$

Prevalensi obesitas yang terus meningkat menjadi salah satu hal yang dikhawatirkan di Indonesia. Di Jawa Barat prevalensi berat badan berlebih pada anak usia 6-14 tahun pria 7,4\% dan perempuan 4,6 \%. ${ }^{[3]}$ Di Minahasa sendiri dilakukan survei pada salah satu SMK di Tondano dengan hasil 4,30\% remaja laki-laki dan $22,03 \%$ remaja perempuan mengalami obesitas. $^{[4]}$ Berdasarkan Hasil Riset Kesehatan Dasar (Riskesdas) Indonesia tahun 2010 menyatakan prevalensi obesitas pada laki-laki 7,8\% dan pada perempuan 15,5\%. Prevalensi obesitas pada perempuan tertinggi berada di Sulawesi Utara 29,5\%, Bangka Belitung 22,8\% dan Gorontalo 22,1\%. Prevalensi obesitas pada remaja 1315 tahun sebesar 2,5\% sedangkan remaja usia 16-18 tahun sebesar $1,4 \% .^{[5]}$

Obesitas disebabkan oleh beberapa faktor, diantaranya pola makan berlebih, kurang olahraga, dan faktor lingkungan. ${ }^{[6]}$ Peningkatan prevalensi obesitas terjadi akibat pola makan tidak sehat yang komposisinya mengandung lemak dan kolesterol tinggi, namun rendah serat, seperti konsumsi fast food dan soft drink, yang juga dapat berpengaruh pada kadar profil lipid seseorang. ${ }^{[7]}$

Profil lipid di dalam darah terdiri dari berbagai fraksi diantaranya kolesterol total, kolesterol LDL, kolesterol HDL, dan trigliserida. Kelainan metabolisme lipid yang ditandai dengan peningkatan maupun penurunan fraksi lipid di dalam plasma darah disebut dislipidemia. Kelainan fraksi lipid yang paling utama adalah kenaikan kadar kolesterol total $(\geq 200 \mathrm{mg} / \mathrm{dl})$, kolesterol LDL $(\geq 100 \mathrm{mg} / \mathrm{dl})$, kenaikan kadar trigliserida $(\geq 150 \mathrm{mg} / \mathrm{dl})$ serta penurunan kadar HDL $(<40 \mathrm{mg} / \mathrm{dl}) .{ }^{[8]}$ Dislipidemia memiliki hubungan erat dengan terjadinya aterosklerosis dan berujung pada infark miokard akut. ${ }^{[9]}$

Beberapa propinsi di Indonesia seperti Nanggroe Aceh, Sumatra Barat, Bangka Belitung dan Kepulauan Riau mempunyai prevalensi dislipidemia $\geq 50 \%$. ${ }^{[10]} \mathrm{Di}$
Indonesia, angka kejadian hiperkolesterolemia pada penelitian MONICA (Monitoring Trends and Determinants of Cardiovascular Disease) di Jakarta 1988 menunjukkan bahwa kadar rata-rata kolesterol total pada wanita 206,6 mg/dl (13,4\%) dan pria 199,8 mg/dl (11,4\%). Kemudian pada tahun 1993 meningkat menjadi $213 \mathrm{mg} / \mathrm{dl}(16,2 \%)$ pada wanita dan 204,8 mg/dl (14\%) pada pria. Dari laporan hasil penelitian MONICA tahun 2002, diperoleh hiperkolesterolemia $\geq 200$ $\mathrm{mg} / \mathrm{dl}(56.5 \%), \mathrm{HDL} \leq 40 \mathrm{mg} / \mathrm{dl}(47.3 \%)$, LDL $\geq 160 \mathrm{mg} / \mathrm{dl}(28.8 \%)$, trigliserida $\geq$ $160 \mathrm{mg} / \mathrm{dl}$ (22.0\%). ${ }^{[11]}$ Pada obesitas didapatkan $\quad 37 \%$ hiperkolesterolemia borderline (200-239 mg/dl), 46\% kolesterol HDL <40 mg/dl, 31\% kolesterol LDL >130 $\mathrm{mg} / \mathrm{dl}$, dan $51 \%$ trigliserida $>150 \mathrm{mg} / \mathrm{dl}$ sedangkan pada non obesitas, 29\% memiliki total kolesterol $\geq 240 \mathrm{mg} / \mathrm{dl}, 32 \%$ kolesterol HDL $<40 \mathrm{mg} / \mathrm{dl}, 22 \%$ kolesterol LDL >130 mg/dl, dan $24 \%$ trigliserida $>150 \mathrm{mg} / \mathrm{dl}^{[12]}$

Obesitas pada remaja beresiko menjadi obesitas pada saat usia dewasa dan berpotensi dapat menyebabkan penyakit kardiovaskuler dan metabolik. ${ }^{[7]}$ Ukuran antoprometri dan derajat obesitas juga berkaitan dengan kadar lipid darah yang dapat menyebabkan dislipidemia dan berhubungan erat dengan peningkatan tekanan darah dan kadar insulin. ${ }^{[13]}$ Peningkatan lipid kolesterol, trigliserida, maupun LDL dapat terjadi pada obesitas. ${ }^{[14]}$ Penelitian yang dilakukan di Lampung menunjukkan terjadi peningkatan LDL dan penurunan HDL pada obesitas. ${ }^{[15]}$

Obesitas pada remaja saat ini merupakan masalah kompleks yang disebabkan oleh beberapa faktor seperti gaya hidup dan pola makan yang tidak sehat serta aktivitas fisik yang kurang. Penelitian sebelumnya menunjukkan prevalensi obesitas di salah satu SMA di kota Bitung tahun 2014 sebesar 12,40\% yang terdiri dari 2,91\% remaja laki-laki dan 9,5\% remaja perempuan. ${ }^{[16]}$

Berdasarkan uraian masalah di atas dan fakta ilmiah yang diperoleh dari penelitianpenelitian terdahulu, maka penulis tertarik 
untuk meneliti tentang gambaran profil lipid pada remaja obesitas di kota Bitung.

\section{METODE PENELITIAN}

Penelitian ini dilakukan pada bulan Oktober 2015 - Januari 2016 di kota Bitung dengan menggunakan metode deskriptif cross-sectional. Populasi penelitian adalah siswa SMA di kota Bitung. Sampel yang diambil pada penelitian ini adalah siswa SMA di kota Bitung yang mengalami obesitas berdasarkan pengukuran lingkar pinggang. Pengambilan sampel dilakukan dengan mengambil serum darah pada remaja obesitas di kota Bitung. Pemeriksaan sampel darah dilakukan di laboratorium klinik RSUD Ratumbuysang Manado untuk dilihat kadar profil lipid dari sampel penelitian.

\section{HASIL PENELITIAN}

Berdasarkan hasil pada Tabel 1. dapat dilihat prevalensi obesitas pada remaja di kota Bitung sebesar 22,8\% dengan jumlah 220 siswa, yang terdiri dari 59 siswa lakilaki (6,1\%) dan 161 siswa perempuan (16,7\%).

Tabel 1. Prevalensi Obesitas pada Remaja di Kota Bitung

\begin{tabular}{ccrr}
\hline Jenis & \multirow{2}{*}{$\mathrm{n}$} & \multicolumn{2}{c}{ Lingkar Pinggang } \\
\cline { 3 - 4 } Kelamin & & Normal & Obesitas \\
\hline Laki-Laki & \multirow{2}{*}{382} & 323 & 59 \\
& & $\begin{array}{r}(33,4 \%) \\
(6,1 \%)\end{array}$ \\
Perempuan & 584 & $\begin{array}{r}423 \\
(43,8 \%)\end{array}$ & $\begin{array}{r}16,7 \%) \\
\end{array}$ \\
\hline Total & \multirow{2}{*}{966} & $\begin{array}{r}746 \\
(77,2 \%)\end{array}$ & $\begin{array}{r}220 \\
(22,8 \%)\end{array}$ \\
\hline
\end{tabular}

Berdasarkan Tabel 2 didapatkan yang mengalami peningkatan kadar kolesterol total $(>200 \mathrm{mg} / \mathrm{dL})$ berjumlah 13 siswa (26\%), laki-laki sebanyak 2 siswa (4\%) dan perempuan sebanyak 11 siswa (22\%).

Berdasarkan Tabel 3 dapat dilihat yang memiliki kadar HDL di bawah nilai normal ( $<40 \mathrm{mg} / \mathrm{dL}$ untuk laki-laki, $<50 \mathrm{mg} / \mathrm{dL}$ untuk perempuan) berjumlah 31 siswa (62\%), laki-laki sebanyak 4 siswa (8\%) dan perempuan sebanyak 27 siswa (54\%).
Tabel 2. Distribusi Kadar Kolesterol Total Menurut Jenis Kelamin

\begin{tabular}{ccccccc}
\hline \multirow{2}{*}{ Jenis } & \multicolumn{4}{c}{ Kolesterol Total } & \multicolumn{2}{c}{ Total } \\
Kelamin & Normal & \multicolumn{2}{c}{ Abnormal } & \multicolumn{2}{c}{} \\
\cline { 2 - 5 } & $\mathrm{n}$ & $\%$ & \multicolumn{1}{c}{$\mathrm{n}$} & $\%$ & $\mathrm{n}$ & $\%$ \\
\hline Laki-laki & 10 & 20 & 2 & 4 & 12 & 24 \\
Perempuan & 27 & 54 & 11 & 22 & 38 & 76 \\
\hline Total & 37 & 74 & 13 & 26 & 50 & 100 \\
\hline
\end{tabular}

Tabel 3. Distribusi Kadar HDL Menurut Jenis Kelamin

\begin{tabular}{|c|c|c|c|c|c|c|}
\hline \multirow{3}{*}{$\begin{array}{c}\text { Jenis } \\
\text { Kelamin }\end{array}$} & \multicolumn{4}{|c|}{ HDL } & \multirow{2}{*}{\multicolumn{2}{|c|}{ Total }} \\
\hline & \multicolumn{2}{|c|}{ Normal } & \multicolumn{2}{|c|}{ Abnormal } & & \\
\hline & $\mathrm{n}$ & $\%$ & $\mathrm{n}$ & $\%$ & $\mathrm{n}$ & $\%$ \\
\hline Laki-laki & 8 & 16 & 4 & 8 & 12 & 24 \\
\hline Perempuan & 11 & 22 & 27 & 54 & 38 & 76 \\
\hline Total & 19 & 38 & 31 & 62 & 50 & 100 \\
\hline
\end{tabular}

Tabel 4. Distribusi Kadar LDL Menurut Jenis Kelamin

\begin{tabular}{|c|c|c|c|c|c|c|}
\hline \multirow{3}{*}{$\begin{array}{c}\text { Jenis } \\
\text { Kelamin }\end{array}$} & \multicolumn{4}{|c|}{ LDL } & \multirow{2}{*}{\multicolumn{2}{|c|}{ Total }} \\
\hline & \multicolumn{2}{|c|}{ Normal } & \multicolumn{2}{|c|}{ Abnormal } & & \\
\hline & $\mathrm{n}$ & $\%$ & $\mathrm{n}$ & $\%$ & $\mathrm{n}$ & $\%$ \\
\hline Laki-laki & 1 & 2 & 11 & 22 & 12 & 24 \\
\hline Perempuan & 8 & 16 & 30 & 60 & 38 & 76 \\
\hline Total & 9 & 18 & 41 & 82 & 50 & 100 \\
\hline
\end{tabular}

Berdasarkan hasil pada Tabel 4 didapatkan yang mengalami peningkatan kadar LDL diatas nilai normal $(\geq 100$ $\mathrm{mg} / \mathrm{dL}$ ) sebanyak 41 siswa (82\%), laki-laki sebanyak 11 siswa (22\%) dan perempuan sebanyak 30 siswa (60\%).

Tabel 5. Distribusi Kadar Trigliserida Menurut Jenis Kelamin

\begin{tabular}{ccccccc}
\hline \multirow{2}{*}{ Jenis } & \multicolumn{4}{c}{ Trigliserida } & \multirow{2}{*}{ Total } \\
\cline { 2 - 5 } Kelamin & Normal & \multicolumn{2}{c}{ Abnormal } & & \\
\cline { 2 - 5 } & $\mathrm{n}$ & $\%$ & $\mathrm{n}$ & $\%$ & $\mathrm{n}$ & $\%$ \\
\hline Laki-laki & 11 & 22 & 1 & 2 & 12 & 24 \\
Perempuan & 33 & 66 & 5 & 10 & 38 & 76 \\
\hline Total & 44 & 88 & 6 & 12 & 50 & 100 \\
\hline
\end{tabular}

Tabel 5 menunjukkan yang mengalami peningkatan kadar trigliserida diatas nilai normal $(\geq 150 \mathrm{mg} / \mathrm{dL})$ berjumlah 6 siswa (12\%), 1 siswa laki-laki (2\%) dan 5 siswa perempuan (10\%). 


\section{BAHASAN}

Dari penelitian yang telah dilakukan di kota Bitung terhadap 966 siswa diperoleh 220 siswa (22,8\%) yang mengalami obesitas berdasarkan pengukuran lingkar pinggang. Angka tersebut digolongkan cukup tinggi dalam menunjukkan kejadian obesitas pada suatu kelompok. Prevalensi obesitas berdasarkan hasil pada tabel 2 . menunjukkan prevalensi remaja obesitas di kota Bitung sebanyak 59 siswa laki-laki (6,1\%) dan 161 siswa perempuan (16,7\%). Penelitian yang sama sebelumnya dilakukan di kabupaten Minahasa menunjukkan prevalensi obesitas sebesar $26,33 \%$. ${ }^{[4,14]}$

Berdasarkan hasil riset kesehatan dasar yang diperoleh dari (RISKESDAS) tahun 2013 yang dikeluarkan kementerian kesehatan ditemukan bahwa prevalensi obesitas berdasarkan indikator lingkar perut pada remaja usia $\geq 15$ tahun sebesar $26,6 \%$. Prevalensi tersebut meningkat dari RISKESDAS 2007 yang hanya sebesar $18,8 \%{ }^{[17]}$

Faktor-faktor penyebab obesitas antara lain pola makan yang tidak sehat seperti makan makanan yang tinggi kalori seperti makanan cepat saji (fast food) serta kurangnya aktifitas fisik. Gaya hidup seperti itu membuat tidak seimbangnya energi yang masuk dan energi yang keluar dalam tubuh yang mengakibatkan tertimbunnya lemak sehingga mengalami obesitas. ${ }^{[18,19]}$

Obesitas pada remaja dapat beresiko menjadi obesitas dewasa yang kemudian berpotensi tinggi terkena penyakit gangguan metabolik, hipertensi, dan penyakit degeneratif di kemudian hari. Obesitas juga dapat mempengaruhi kadar profil lipid dalam darah dan menyebabkan terkena penyakit kardiovaskuler. ${ }^{[13]}$

Dari 50 sampel yang bersedia menjadi sampel penelitian untuk dilakukan pengambilan sampel darah, terdapat 13 siswa (26\%) yang memiliki kadar kolesterol di atas nilai normal $(\geq 200$ $\mathrm{mg} / \mathrm{dL}$ ), 2 siswa laki-laki (4\%) dan 11 siswa perempuan (22\%) yang dapat dilihat pada tabel 3. Pada tabel 4. menunjukkan distribusi kadar HDL di bawah nilai normal ( $<40 \mathrm{mg} / \mathrm{dL}$ untuk laki-laki, $<50 \mathrm{mg} / \mathrm{dL}$ untuk perempuan) sebanyak 31 siswa (62\%), 4 siswa laki-laki (8\%) dan 27 siswa perempuan (54\%).

Pada tabel 5. menunjukkan distribusi kadar LDL menurut jenis kelamin, dimana terdapat 41 siswa (82\%) yang memiliki kadar LDL diatas nilai normal $(\geq 100$ $\mathrm{mg} / \mathrm{dL}), 11$ siswa laki-laki (22\%) dan 30 siswa perempuan (60\%). Sedangkan pada tabel 6. menunjukkan sebanyak 6 siswa (12\%) memiliki kadar trigliserida diatas nilai normal $(\geq 150 \mathrm{mg} / \mathrm{dL}), 1$ siswa lakilaki (2\%) dan 5 siswa perempuan (10\%). Penelitian yang sama dilakukan di SMP Negeri 1 Manado tahun 2014 oleh Astrid Iksan menunjukkan hasil yang serupa dimana terjadi dislipidemia pada remaja yang mengalami obesitas. ${ }^{[13]}$

Berdasarkan hasil RISKESDAS 2013 nasional yang dilakukan pada masyarakat Indonesia usia $\geq 15$ tahun didapatkan hasil sebesar 25,8\% memiliki kadar koleterol yang termasuk kategori borderline (200$239 \mathrm{mg} / \mathrm{dL}$ ) dan 10,1\% masuk kategori tinggi. Proporsi HDL rendah $(<40)$ pada umur $\geq 15$ tahun sebesar 22,9\%. Proporsi LDL abnormal sebesar 26\% masuk kategori borderline tinggi (130-159 $\mathrm{mg} / \mathrm{dL}$ ), 11,1\% masuk kategori tinggi (160$189 \mathrm{mg} / \mathrm{dL}$ ), dan 4,8\% masuk kategori tinggi ( $\geq 190 \mathrm{mg} / \mathrm{dL})$. Sedangkan proporsi trigliserida abnormal sendiri sebesar 13\% masuk kategori borderline tinggi (150-199 $\mathrm{mg} / \mathrm{dL}$ ), 11,4\% masuk kategori tinggi (200$499 \mathrm{mg} / \mathrm{dL}$ ) dan 0,5\% masuk kategori sangat tinggi $(\geq 500 \mathrm{mg} / \mathrm{dL}){ }^{[17]}$

Ketidakseimbangan atau kelainan metabolisme lipid yang ditandai peningkatan atau penurunan fraksi lipid dalam darah disebut dislipidemia. ${ }^{[8]}$ Dislipidemia dapat berdampak pada terjadinya aterosklerosis dan berujung pada infark miokard akut. ${ }^{[9]}$ Keadaan kadar LDL yang tinggi dan kadar HDL yang rendah akan menyebabkan dinding pembuluh darah akan semakin menebal yang mengakibatkan terjadinya aterosklerosis. ${ }^{[15]}$ Dislipidemia merupakan faktor risiko mayor untuk terjadinya PJK, dengan 
tingginya kadar kolesterol total, Low Density Lipoprotein (LDL), dan trigliserida serta rendahnya kadar High Density Lipoprotein (HDL) dapat meningkatkan risiko penyakit jantung koroner dan stroke iskemik. ${ }^{[19,20]}$

Gaya hidup modern di kota saat ini membuat masyarakat sulit untuk menghindari makanan fast food yang banyak mengandung kalori dan lemak tinggi. Remaja saat ini cenderung mengonsumsi makanan cepat saji dan jajanan yang tidak sehat akibat pengaruh teman sebaya maupun keadaan lingkungan. Kurangnya aktifitas fisik dan akibat pergaulan di lingkungan yang tidak sehat dapat meningkatkan resiko terjadinya obesitas. Faktor-faktor itulah yang dapat menimbulkan obesitas akibat penumpukan lemak di jaringan adiposa dan meningkatkan kadar kolesterol dalam darah.

Tingginya kadar kolesterol dalam tubuh menjadi pemicu timbulnya berbagai macam penyakit. Pola makan sehat merupakan faktor utama untuk menghindari hal ini. Hindarilah makanan yang mengandung lemak jenuh seperti makanan produk hewani, daging sapi, babi, kambing, kulit ayam atau bebek, cumi, kerang dan goreng-gorengan. Makanan yang rendah lemak dan kaya akan serat seperti buah avokad, kacang-kacangan, sayur dan buah yang dapat menurunkan kadar kolesterol. Beberapa jenis ikan seperti ikan tuna dan salmon memiliki kandungan omega 3 yang dapat mencegah peningkatan kadar kolesterol.

\section{SIMPULAN}

Berdasarkan hasil penelitian dapat disimpulkan bahwa prevalensi remaja yang mengalami obesitas di kota Bitung sebesar 22,8\% (220 siswa). Dari hasil penelitian ini didapatkan 13 siswa (26\%) memiliki kadar kolesterol diatas nilai normal, 31 siswa (62\%) memiliki kadar HDL di bawah nilai normal, 41 siswa (82\%) memiliki kadar LDL di atas nilai normal, dan 6 siswa (12\%) memiliki kadar trigliserida di atas nilai normal.

\section{SARAN}

Bagi peneliti selanjutnya diharapkan dapat melakukan penelitian lebih lanjut tentang gambaran profil lipid pada remaja obesitas dengan jumlah sampel yang lebih banyak agar dapat mewakili populasi dan tidak terbatas pada umur tertentu saja.

\section{DAFTAR PUSTAKA}

1. World Health Organization. Childhood overweight and obesity. [cited 2015 Sept http://www.who.int/dietphysicalactivi ty/childhood/en/

2. World Health Organization. Obesity. [cited 2015 Sept 8] http://www.who.int/topics/obesity/en/

3. Rosita I, Marhaeni D, Mutyara K. Konseling gizi Transtheoritical model dalam mengubah perilaku makan dan aktivitas fisik pada remaja overweight dan obesitas. Bandung: Universitas Padjajaran; 2012.

4. Kussoy K, Fatimawali, Kepel B. Prevalensi obesitas pada remaja di kabupaten minahasa. Jurnal e-biomedik. Juli 2013;1:981-5.

5. Kementerian Kesehatan RI. Badan Penelitian dan Pengembangan Kesehatan. Riset Kesehatan Dasar; 2010.

6. Arofah D. Konsumsi soft drink sebagai faktor resiko terjadinya obesitas pada remaja usia 15-17 tahun (Skripsi). Fakultas Kedokteran Universitas Diponegoro Semarang; 2006.

7. Rafiony A. Konsumsi fast food dan soft drink sebagai faktor resiko obesitas pada remaja SMA di kota Pontianak (Thesis). Yogyakarta: Universitas Gadjah Mada; 2013.

8. Alexander SB. Perbedaan Profil Lipid Pada Pasien Infark Miokard Akut Dan Penyakit Jantung Non Infark Miokard Akut. Jurnal Media Medika Muda. 2013;2.

9. Holzmann, Jungner, Walldius, Ivert, Nordqvist, Ostergren, et al. Dyslipidemia is a strong predictor of myocardial infarction in subjects with chronic kidney disease. Ann Med. 2012;44(3):262-70.

10.Perhimpunan Dokter Spesialis Kardiovaskular Indonesia. Pedoman 
Senduk, Bodhi, Kepel: Gambaran profil lipid...

Tatalaksana Dislipidemia. Edisi

Pertama. Jakarta: Centra

Communications; 2013.

11.Supari F. Profil lipid plasma pada MONICA III tahun 2000. Kumpulan Makalah Seminar Sehari - Presentasi Hasil MONICA Jakarta. Jakarta: Pusat Jantung Nasional Rumah Sakit Jantung dan Pembuluh Darah Harapan Kita. 2002; 1-17.

12.Shah SZA, Devrajani BR, Devrajani T, Bibi I. Frequency of Dyslipidemia in Obese versus Non-obese in relation to Body Mass Index (BMI), Waist Hip Ratio (WHR) and Waist Circumference (WC). Pakistan Journal of Science [serial online]. 2010;62:27-31.

13.Iksan A, Manampiring A, Fatimawali. Gambaran Profil Lipid Pada Siswa Obese di SMP Negeri 1 Manado. Jurnal e-Biomedik. 2015;1:72-9.

14.Damanik N, Manampiring A, Fatimawali. Gambaran kadar trigliserida pada remaja obesitas di kabupaten minahasa. Jurnal e-biomedik. 2013;1:537-42.

15.Ercho NC, Berawi K, Susantiningsih T. Hubungan Obesitas dengan kadar
LDL dan HDL pada mahasiswa preklinik fakultas kedokteran universitas lampung. Jurnal Kedokteran Unila. 2014;3:87-92.

16.Tuerah W, Manampiring A, Fatimawali. Prevalensi obesitas pada remaja di sma kristen tumou tou kota bitung. Jurnal e-biomedik. 2014;2:514-8.

17.Kementerian Kesehatan RI. Badan Penelitian dan Pengembangan Kesehatan. Riset Kesehatan Dasar; 2013.

18.Guyton A, Hall J. Metabolisme Lipid. In: Rachman L, Hartanto H, Novrianti A, Wulandari N, editors. Buku Ajar Fisiologi Kedokteran. Edisi ke-11. Jakarta: EGC Medical Publisher; 2012. h. 882,884,889, 917-8.

19.Zahara F, Syafri M, Yerizel E. Gambaran profil lipid pada pasien sindrom koroner akut di rumah sakit khusus jantung sumatera barat tahun 20112012. Jurnal Kesehatan Andalas. 2013;3(2):167-72.

20.Kandou G. Makanan etnik minahasa dan kejadian penyakit jantung koroner. Jurnal Kesehatan Masyarakat Nasional. 2009;4(1);42-8. 